\title{
India makes headway on climate policy
}

\section{Last week, India laid out an ambitious plan for solar energy. Anna Barnett looks at how far it will go in reducing the country's carbon footprint.}

l: ndian Prime Minister Manmohan Singh last week convened his advisory council on climate change to approve a new solar-energy plan that is among the world's most ambitious. The US $\$ 19$ billion solar plan is the centrepiece of a detailed road map for domestic climate and energy policy to be laid out ahead of international climate negotiations this December.

Meeting for the first time in over a year, the council on 3 August approved targets set out in a draft proposal ${ }^{1}$. Under the proposed plan, solar capacity will be increased from its current 5 megawatts to 20 gigawatts (GW) by 2020, with solar lighting reaching 20 million households and solar panels covering a million roofs. In the longer term, capacity will be extended to $100 \mathrm{GW}$ by 2030 and to $200 \mathrm{GW}$ by 2050 . In comparison, Japan is aiming for $28 \mathrm{GW}$ of solar power by 2020 , and the Chinese government anticipates at least $10 \mathrm{GW}$ by 2020 .

"This should get people off the back of India," says Rajendra Pachauri, a member of Singh's climate council and chairman of the Intergovernmental Panel on Climate Change. The world's fourth largest greenhouse gas emitter, India has been criticized for its adamant resistance to legally binding limits on its future emissions. "Negotiators should see this as India's attempt to go the extra mile," Pachauri says.

A key premise of the Indian plan is that subsidizing a solar industry scale-up will reduce costs so that by 2030 solar power is no more expensive than fossil fuels. Solar energy currently costs over four times more than fossil fuel-based energy, but the business models and production lines needed to start on cutting costs are already in place, says Shirish Sinha, head of climate change and energy at the Worldwide Fund for Nature India in New Delhi. "It's an ambitious plan, but it's a doable plan," Sinha says.

By itself, the plan will make only a small difference to the country's carbon footprint. By 2020 the solar splurge will save 42 million tonnes of carbon dioxide from entering the atmosphere annually. That's just two per cent of the total annual energy-

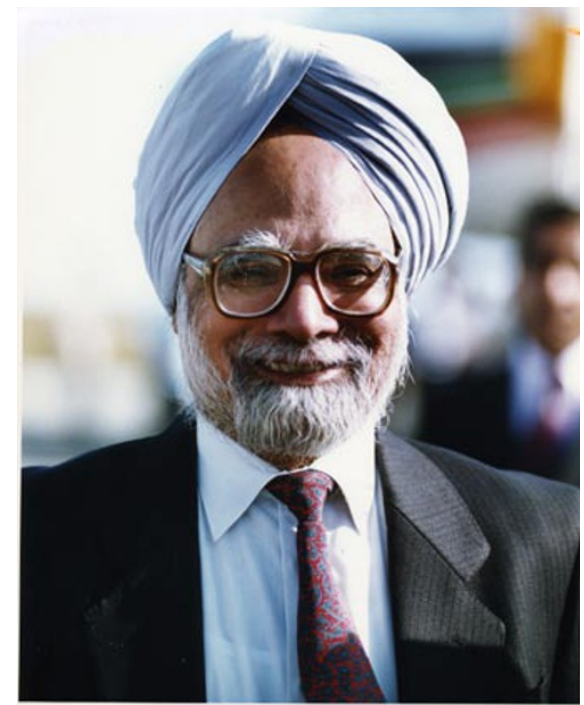

Indian Prime Minister Manmohan Singh.

related emissions projected for India in 2020, according to figures from the International Energy Agency ${ }^{2}$. But the 'solar mission' is one of eight pathways outlined in India's National Action Plan on Climate Change in 2008, and once details are announced for other national missions - which focus on topics ranging from energy efficiency to sustainable habitats - the overall package is likely to cut emissions by about five to six per cent from business as usual.

Given the country's very low per capita emissions - about one-fourth the global average - "it would be unfair and unethical to expect India to do any more than this," says Pachauri. M. V. Ramana, an expert on Indian energy policy at Princeton University in New Jersey, says, "There is no agreement on how much, or whether at all, developing countries need to reduce emissions. If and when there is agreement on that, 42 million tonnes may well be significant."

Pachauri says the climate council and liaising government agencies put in a flurry of work last year to flesh out proposals for the national missions. By the time governments meet in Copenhagen to agree a global climate deal, India is hoping that these efforts will be seen as evidence of its willingness to act. They may also serve as a shop window for industrialized countries deliberating over international funding for such programs. "The National Action Plan represents what India intends to accomplish within the limitation of its own resources. Obviously, with a supportive global climate regime, we will be able to scale up our efforts," says Shyam Saran, the prime minister's special envoy on climate change.

"My understanding is that as far as the 2020 target is concerned, India is determined to do that by getting resources - beg, borrow, or steal - on its own," says Pachauri. "But when you go beyond that, to 2030 and 100,000 megawatts, that's something India would like to seek support for." That type of two-part message needs to be articulated with care, suggests Ramana. While the government is now promising billions to boost solar power, it has also argued that it can't afford carbon-cutting measures given its urgent development goals - not least expanding its largely coal-fired electricity supply, to which 56 per cent of Indians lack access. What's needed, Ramana says, is a clearer sustainable development vision that would marry such aims. "India is in the early stages of coming up with a climate policy, but the effort is still quite scattered," he says.

The effort is likely to tighten in the coming months: in addition to the shower of planning documents, India heads into bilateral climate talks with China in August and with the United States in September, and will host a high-level conference on technology transfer in October.

Published online: 13 August 2009

\section{doi:10.1038/climate.2009.79}

\section{References}

1. Jayaraman, K. Nature doi:10.1038/news.2009.774 (2009)

2. World Energy Outlook 2008385 (International Energy Agency, Paris, 2008).

Anna Barnett is assistant editor and copy editor of Nature Reports Climate Change. 